\title{
CHANGES IN TREHALOSE CONTENT OF BAKER'S YEAST AS AFFECTED BY OCTANOIC ACID
}

\author{
L.E. GUTIERREZ \\ Departamento de Qufmica, ESALQ/USP, C.P. 9, CEP: 13.418-900 Piracicaba,SP
}

\begin{abstract}
SUMMARY: Octanoic acid inhibited ethanolic fermentation by Saccharomyces cerevisiae (bakers yeast) and the trehalose accumulation, however did not affect the endogenous degradation of trehalose. This inhibition may be explained by the binding of octanoic acid to hexokinase or other proteins of plasma membrane because they are not necessary for endogenous fermentation. The degradation of trehalose may be due to an activation of trehalase.

Keg Wonds: trehalose, yeast, Saccharomyces, octanoic acid.
\end{abstract}

\section{ALTERAÇŌES NO TEOR DE TREALOSE de LEVEduRA de PANIFICAÇĀo PROVOCADAS POR ÁCIDO OCTANÓICO}

RESUMO: A adição de ácido octanóico inibiu a fermentação alcoólica realizada por Saccharomyces cerevisiae (levedura de panificação) e o acúmulo de trealose, contudo não afetou a degradação endógena de trealose. Esta inibição poderia ser explicada pela ligação do ácido octanóico a hexoquinase ou outra proteína da membrana plasmática porque nāo sẫo necessárias para a fermentação endogena. A degradação da trealose poderia ser devida a uma ativação da trealase.

Descritores: trealose, leveduras, acido octanóico, Saccharomyces.

\section{INTRODUCTION}

Octanoic and decanoic acids are minor components produced during alcoholic fermentation (LAFON-LAFOURCADE, 1983) but, even in low concentration, it has been found that they have a significant effect on alcoholic fermentation (LAFON-LAFOURCADE et al., 1984). The toxicity of both acids increased in the presence of ethanol which could explain the higher effect of ethanol produced during fermentation than the added ethanol (VIEGAS et al., 1985; SÁCORREIA, 1986).

In an investigation of the effect of octanoid and decanoic acids on the inhibition of fermentation by yeasts, it was observed that both acids decreased the biomass at $30^{\circ} \mathrm{C}$ and that decanoic acid was more toxic than octanoic acid (VIEGAS et al., 1989).

NORDSTROM (1964) reported that the inhibitory action of lower fatty acids on yeasts could be partly due to the interference with essential metabolic activities requiring acyl-CoAcompounds while FERDINANDUS \& CLARK (1969) verified an inhibition of bacterial enzymes phosphofructokinase, pyruvate kinase, glucose-6phosphate dehydrogenase by octanoic acid.

Studying the effect of acetic acid on ethanolic fermentation, GUTIERREZ et al. (1991) verified that there was less accumulation of trehalose with lower biomass production.

This paper describes the effect of octanoic acid on trehalose accumulation and suggests that its mode of action could be explained by activation of trehalase.

\section{MATERIALS AND METHODS}

Microorganism. The yeast used in this study was a strain of baker's yeast (Saccharomyces cerevisiae), trade mark Fleischmann.

Fermentation conditions. Fermentation experiments were carried out in $500 \mathrm{ml}$ conical flasks capped with aluminium foil, containing $250 \mathrm{ml}$ of potassium citrate buffer $\mathrm{pH} 4.0$ or $5 \%$ glucose in the same buffer. Additions of ethanolic solutions of octanoic acid were made to produce final concentrations of $48,96,120,180$ and $240 \mathrm{mg} / \mathrm{L}$. They were inoculated with $20 \mathrm{mg} / \mathrm{ml}$ of fresh 
bakers yeast cells and incubated at $40^{\circ} \mathrm{C}$. Samples were withdrawn at zero time and as appropriate thereafter for determinations of trehalose and reducing sugars. All analyses were made in triplicate and all the reagents were of analytical grade.

Trehalose. Yeast cells were collected by centrifugation at $1,000 \times \mathrm{g}$ for $10 \mathrm{~min}$ and washed with cold distilled water. Trehalose was extracted from yeast cells by $0.5 \mathrm{M}$ trichloroacetic acid and determined by the anthrone method (BRIN, 1966).

Reducing sugars. Sugars present in the medium were estimated by the modified method of Somogyi-Nelson (AMORIM et al., 1982).

\section{RESULTS AND DISCUSSION}

Octanoic acid inhibited exogenous fermentation of glucose by Saccharomyces cerevisiae (bakers yeast) in nonproliferant conditions (Fig.1) as has already pointed out (LAFON-LAFOURCADE et al., 1984; VIEGAS et al., 1985; VIEGAS et al., 1989; VIEGAS \& SACORREIA, 1991).

Figure 2 shows that octanoic acid inhibited trehalose accumulation in the $5 \%$ glucose medium, and did not affect the endogenous degradation of trehalose in citrate buffer (Fig.3).

The lack of inhibition of endogenous fermentation by octanoic acid at concentrations which suppressed exogenous fermentation indicates that the primary point must be on hexokinase and/or sugar transport across the plasma membrane in a mechanism similar to iodoacetate (BRADY et al., 1961) and uranyl ion (ROTHSTEIN et al., 1951).

The means by which octanoic acid prevents glucose fermentation is still not clear. Some bacterial enzymes of glycolysis were inhibited by octanoic acid (FERDINANDUS \& CLARK, 1969). Besides inhibiting phosphate uptake by yeast cells, there is some evidence that at least two glycolytic enzymes are inhibited by short-fatty acids (SAMSON et al., 1955). The effect of lower fatty acids may be explained by a decrease in internal $\mathrm{pH}$ values which are inhibitory to hexokinase and phosphofructokinase activities (KREBS et al., 1983) however VIEGAS \& SÁCORREIA (1991) did not observe differences in the internal $\mathrm{pH}$ in yeast cells incubated with octanoic acid.

The synthesis of trehalose in yeast was reduced in the presence of 2,4-dinitrophenol (BERKE \& ROTHSTEIN, 1957; AMIN et al., 1984; GUTIERREZ, 1990). Dinitrophenol makes membrane permeable to protons inhibiting the yeast protonpumping ATPase (SERRANO, 1980). The reduction of trehalose levels by octanoic acid shown in Figures 2 and 3 may be explained by changes in the activity of plasma membrane ATPase because VIEGAS \& SÁ-CORREIA(1991) observed a higher activity of the enzyme in yeast cells grown in the presence of octanoic acid and BORST et al.(1962) reported that long-chain fatty acids were also effective in stimulating ATPase activity of rat-liver mitochondria.

The activation of trehalase by octanoic acid could explain the immediate increase in trehalose endogenous degradation observed in Fig. 3 in the same way as 2,4-dinitrophenol (THEVELEIN, 1984) and also explain the level of reducing sugars found in the medium (Fig.4).

But VALLE et al. (1986) have reported that the activation of trehalase is mediated by an intracelular acidification caused by glucose and uncouplers. Irreversible toxicity resulting in the fall of trehalose contents may explain cell death of baker's yeast when exposed to octanoic acid.

The low concentration of short-chain fatty acids necessary to inhibt exogenous but not endogenous fermentation in yeast cells could be explained by the binding of octanoic acid to hexokinase and/or proteins of membrane because they are not necessary for endogenous fermentation.

\section{ACKNOWLEDGEMENTS}

This work was supported by FERMENTEC - Assessoria em Fermentação Alcoólica (Brasil). The author would also like to thank Mrs Margareth Wagner for reading and correcting this manuscript and Mr. Luis Lucatti for technical assistance. 


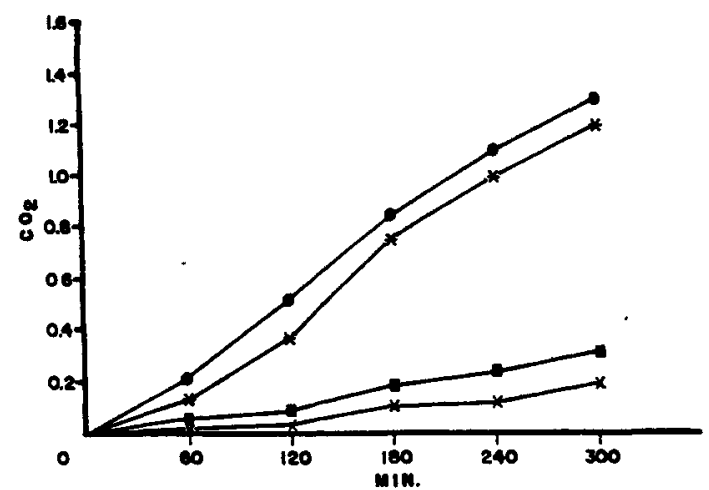

FIQURE 1. EFFECT OF OCTANOIC ACID ON ALCOHOLIC FERMENTATION $120 \mathrm{mo} / \mathrm{mL}$ FRESH BAKER'S , $5 \%$ GLUCOSE IN K CITRATE DH 401 . TOTAL OCTANOIC ACID CONCENTRATIONS: CONTROL $(0), 48(*), 96(\mathbb{1}), 120(x) \mathrm{mg} / \mathrm{L}$.

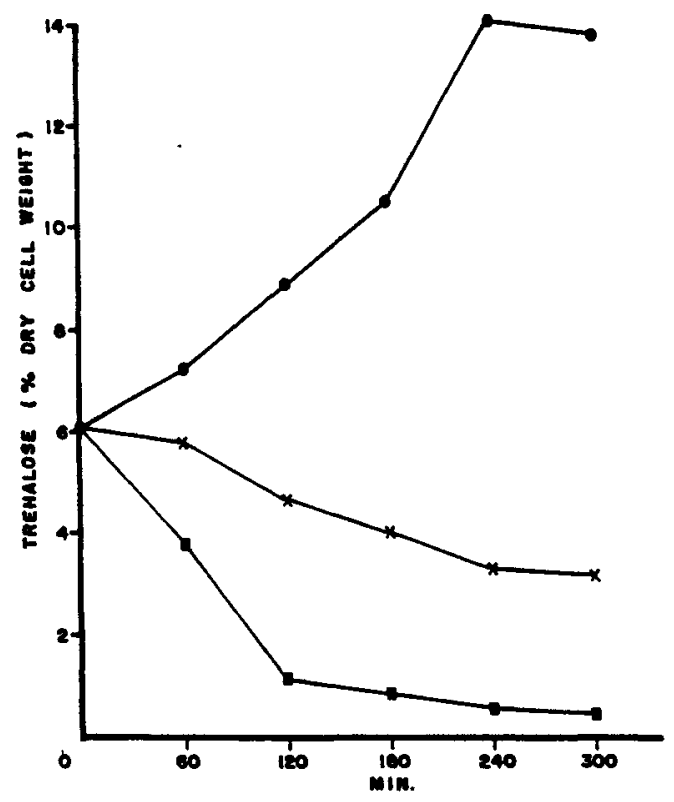

FIGURE 2 . EFFECT OF OCTANOIC ACID ON TREHALOSE LEVELS DUNINE EXOEENOUS FERMENTATION $/ 20 \mathrm{mg} / \mathrm{mL}$ FRESH BAKER'S YEAST - $5 \%$ GLUCOSE - $K$ CITRATE DH 401 . TOTAL OCTANOIC CONCENTRATIONS: Control $(0), 120(x), 180(\theta) \mathrm{mg} / \mathrm{h}$.

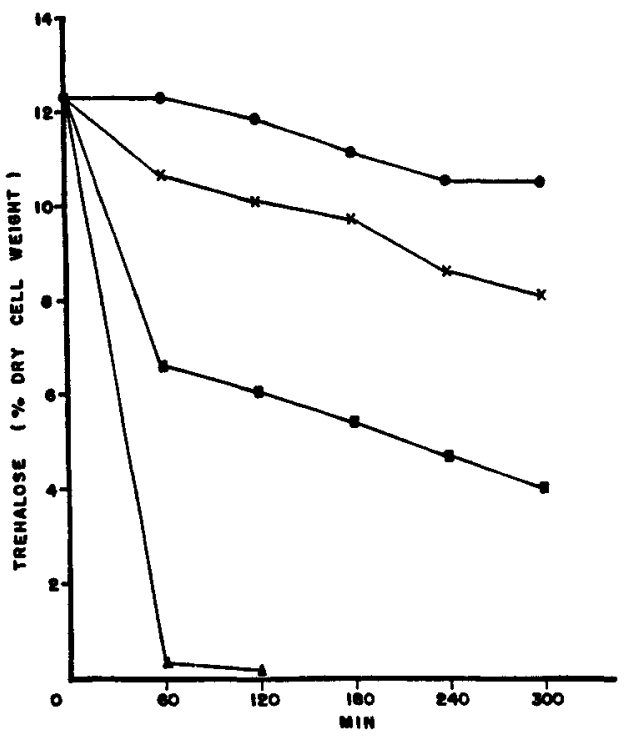

FIGURE 3 EFFECT OF OCTANOIC ACID ON TREHALOSE LEVELS DURING ENDOGENOUS FERMENTATION $120 \mathrm{mg} / \mathrm{mL}$ FRESH BAKER'S YEAST, K CITRATE DH 401 1.TOTAL OCTANOIC ACID CONCENTRATIONS CONTROL $(0)$. $120(x), 180(1), 240(A) \mathrm{mg} / \mathrm{L}$

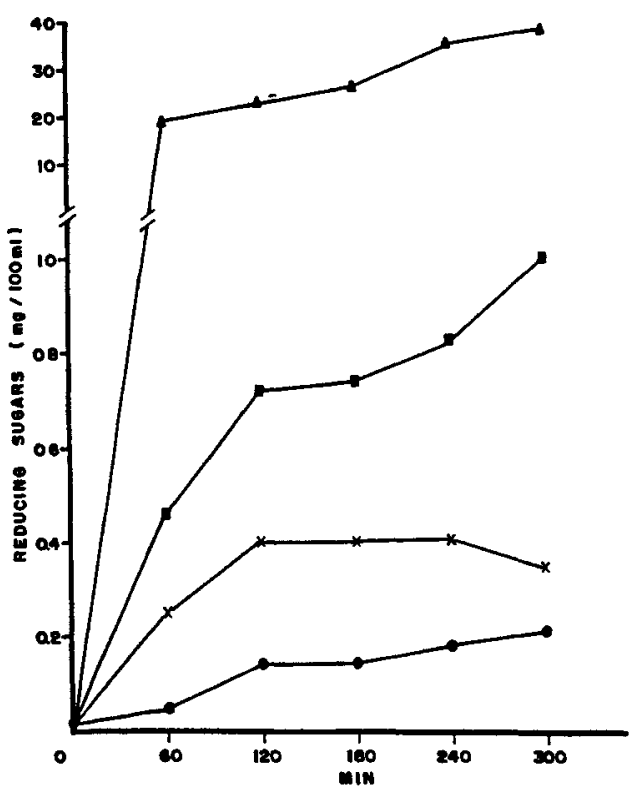

FIGURE 4: EFFECT OF OCTANOIC ACID OK MEOIUM REOUCINB SUEARS $120 \mathrm{mg} / \mathrm{mL}$ FRESH BAKER's VEAST, $K$ CITRATE OH 401 . TOTAL octanoic aCid concentrations: CONTAOL $(\theta)$, $120(x), 100(1), 240(10) m / L$ 


\section{REFERENCES}

AMIN, G.; STANDAERT, P.; VERACHTERT, H. Effects of metabolic inhibitors on the alcoholic fermentation by several yeasts in batch or in immobilized cell systems. Applied Microbiology and Biotechnology, Berlin, v.19, p.91-99, 1984.

AMORIM, H.V.; ZAGO, E.A. ; OLIVEIRA, A.J. Novos métodos para o controle da fermentação alcoblica. São Paulo: Sociedade Brasileira de Microbiologia, 1982. 58p.

BERKE, H.L.; ROTHSTEIN, A. The metabolism of storage carbohydrates in yeast, studied with glucose1-C ${ }^{14}$ and dinitrophenol. Archives of Biochemistry and Biophysics, San Diego, v.72, p.380-395, 1957.

BORST, P.; LOOS, J.A.; CHRIST, E.J.; SLATER, E.C. Uncoupling activity of long-chain fatty acids. Biochimica et Biophysica Acta, Amsterdan, v.62, p.509-518, 1962.

BRADY, T.G.; DUGGAN, P.F.; McGANN, C.; TULLY, E. Study of the endogenous fermentation induced in bakers yeast by azide, 2,4-dinitrophenol and arsenite. Archives of Biochemistry and Biophysics, San Diego, v.93, p.220-230, 1961.

BRIN, M. Transketolase: clinical aspects. Methods in Enxymology, San Diego, v.9, p.506-514, 1966.

FERDINANDUS, J.; CLARK, J.B. Selective inhibition of bacterial enzymes by free fatty acids. Journal of Bacteriology, Washington, v.98, n.3, p.1109-113, 1969.

GUTIERREZ, L.E. Acúmulo de trealose em linhagens de Saccharomyces durante fermentação alcoólica. Anais da Escola Superior de Agricultura "Luia de Queiroz", v.47, n.2, p.597-607, 1990.

GUTIERREZ, L.E.; ANNICCHINO, A.V.K.O.; LUCATTI, L.; STIPP, J.M.S. Efeitos do ácido acético sobre a fermentação alcoólica. Arquivos de Biologia e Tecnologia, Curitiba, v.34, n.2, p.235-242, 1991.

KREBS, H.A.; WIGGINS, D.; STUBBS, M.; SOLS, A.; BEDOYA, F. Studies on the mechanism of the antifungal action of benzoate. Biochemical Journal, Essex, v.214, p.657-663, 1983.

LAFON-LAFOURCADE, $s$. Wine and brandy. In: REED, G., ed. Biotechnology. Weinhein: Veriag Chemie, 1983, vol.5, p.81-163.

LAFON-LAFOURCADE,S.; GENEIX, C.; RIBEREAUGAYON, P. Inhibition of alcoholic fermentation of grape must by fatty acids produced by yeasts and their elimination by yeast ghosts. Applied and Environmental Microbiology, Washigton. v.47, n.6, p.1246-1249, 1984.
NORDSTROM, K. Formation of esters from acids by brewers yeast.IV. Effect of higher fatty acids and toxicity of lower fatty acids. Journal of the Institute of Brewing, London, v.70, p.233-242, 1964.

ROTHSTEIN, A.; MEIER, R.; HURWITZ, L. The relation of the surface to metabolism. $V$. The role of uranium-complexing loci of yeast in metabolism. Journal of Cellular Comparative Physiology, New York, v.37, p.57-82, 1951.

SA-CORREIA, I. Synergistic effects of ethanol, octanoic and decanoic acids on the kinetics and the activation parameters of thermal death in Saccharomyces bayanus. Biotechnology \& Bioengineering, New York, v.28, p.761-763, 1986.

SAMSON, F.E.; KATZ, A.M.; HARRIS, D.L. Effects of acetate and other short-chain fatty acids on yeast metabolism. Archives of Biochemistry and Biophysics, San Diego, v.54, p.406-423, 1955.

SERRANO, R. Effect of ATPase inhibitors on the proton pump of respiratory-deficient yeast. European Journal of Biochemistry, Berlin, v.105, n.2, p.419$424,1980$.

THEVELEDN, J.M. Activation of trehalase by membranedepolarizing agents in yeast vegetative cells and ascospores. Journal of Bacteriology, Washington, v.158, n.1, p.337-339, 1984.

VALLE, E.; BERGLLOS, L.; GASCON, S.; PARRA, F.; RAMOS, $S$. Trehalase activation in yeasts is mediated by an internal acidification. Europenn Journal of Biochemistry, Berlin, v.154, p.247-251, 1986.

VIEGAS, C.A.; SA-CORREIA, I.; NOVAIS, J.M. Synergistic inhibition of the growth of Saccharomyces bayanus by ethanol and octanoic or decanoic acids. Biotechnology Letters, Middlesex, v.7, n.8, p.611614, 1985.

VIEGAS, C.A.; ROSA, M.F.; SÁ-CORREIA, I.; NOVAIS, J.M. Inhibition of yeast growth by octanoic and decanoic acids produced during ethanolic fermentation. Applied and Environmental Microbiology, Washington, v.55, n.1, p.21-28, 1989.

VIEGAS, C.A.; SA-CORRELA, I. Activation of plasma membrane ATPase of Saccharomyces cerevisiae by octanoic acid. Journal of General Microbiology, Reading, v.137, p.645-651, 1991.

Received May 26, 1993

Accepted July 16, 1993

Enviado para publicação em 26.05 .93

Aceito para publicação em 16.07 .93 